The Bangladesh Veterinarian (2012) 29(2) : 41 - 48

\title{
Isolation and identification of Newcastle disease viruses from field outbreaks in chickens and pigeons
}

\author{
A. C. Mazumder, S. Khatun, M. Nooruzzaman*, E. H. Chowdhury, P. M. Das and \\ M. R. Islam \\ Department of Pathology, Faculty of Veterinary Science, Bangladesh Agricultural \\ University, Mymensingh-2202, Bangladesh
}

\begin{abstract}
Eleven dead or sick birds submitted from farms in the year 2010 with a history of sudden death with respiratory and/or diarrhoeal signs were used for isolation and identification of Newcastle disease virus (NDV). All samples were subjected to routine necropsy. Pooled respiratory tissues were inoculated in embryonated chicken eggs and chicken embryo fibroblast (CEF) cell culture. The growth of NDV was confirmed by embryo mortality, cytopathic effects (CPE) in cell culture, haemagglutination (HA) and haemagglutination inhibition (HI) test. The presence of NDV was confirmed by reverse transcriptionpolymerase chain reaction (RT-PCR). At necropsy seven cases were tentatively diagnosed as Newcastle disease (ND). Out of seven ND-suspected samples, four yielded virus in both embryos and cell culture, while one was positive only in embryos, one only in cell culture and one sample was negative in both embryos and cell culture. RT-PCR successfully amplified a $766 \mathrm{bp}$ fragment covering parts of Matrix and Fusion protein genes of NDV from the samples that were positive either in embryos or in cell culture. It is suggested that RT-PCR could be a rapid and sensitive tool for the detection of NDV. (Bangl. vet. 2012. Vol. 29, No. 2, $41-48$ )
\end{abstract}

\section{Introduction}

Newcastle disease virus or Avian Paramyxovirus- 1 is an enveloped negative sense single-stranded RNA virus containing a genome of approximately $15 \mathrm{kbp}$ (Lamb and Kolakofsky, 2001). Kaleta and Baldauf (1988) suggested that Newcastle disease virus (NDV) infections had been established in at least 241 species of birds representing 27 of the 50 orders of the class Aves. Signs of ND vary in severity and lethality, but usually include respiratory distress, diarrhoea, circulatory disturbances and central nervous system impairment (Alexander, 1997). Isolation of NDV in embryonated chicken eggs and its identification by haemagglutination (HA) and and haemagglutination inhibition (HI) tests with an NDV-monospecific antiserum (Alexander, 2009) is considered to be the gold standard. In recent years reverse transcription-polymerase chain reaction (RT-PCR) has been applied to identify NDV (Jestin and Jestin, 1991; Kant et al., 1997; Gohm et al., 2000; Zhang et al., 2010).

\footnotetext{
*Corresponding Author:- E-mail: khokondvm@yahoo.com
} 
Velogenic viscerotrophic NDV is endemic in Bangladesh causing significant mortality (Talha et al., 2001). NDV has been isolated earlier from chickens in Bangladesh (Chowdhury et al., 1981; Saha et al., 1998; Noor et al., 2005; Barman et al., 2010). The present study reports isolation and identification of NDV from recent field outbreaks in chickens and pigeons and as well as detection of NDV by RT-PCR.

\section{Materials and Methods}

\section{Samples}

Eleven dead or sick birds received from poultry farms with a history of sudden death with or without respiratory or diarrhoeal signs in the year 2010 were included (Table 1). The birds were subjected to routine post-mortem examination and the gross lesions were recorded. Representative tissue samples from the respiratory system (larynx, trachea and lungs) were collected for virological and histopathological investigation.

Table 1. Description of samples investigated in the study

\begin{tabular}{|c|c|c|c|}
\hline Sample No. & Type of bird & Age & Clinical presentation \\
\hline C-21 & Cockerel & 28 days & Drowsiness and respiratory signs \\
\hline C-39 & Broiler & 5 days & Drowsiness and respiratory signs \\
\hline C- -40 & Broiler & 8 days & Drowsiness, respiratory signs and diarrhoea \\
\hline C-50 & Layer & 15 weeks & $\begin{array}{c}\text { Drowsiness, inappetance, and white watery } \\
\text { diarrhoea }\end{array}$ \\
\hline C-56 & Broiler & 21 days & $\begin{array}{c}\text { Drowsiness, inappetance and white watery } \\
\text { diarrhoea }\end{array}$ \\
\hline C-67 & Layer & 21 days & Drowsiness, inappetance and respiratory signs \\
\hline C-139 & Layer & 27 weeks & Sudden death \\
\hline C-161 & Layer & 28 weeks & $\begin{array}{l}\text { Drowsiness, inappetance and white watery } \\
\text { diarrhoea }\end{array}$ \\
\hline C-162 & Broiler & 21 days & $\begin{array}{l}\text { Drowsiness, inappetance, white watery } \\
\text { diarrhoea and salivation }\end{array}$ \\
\hline C-308 & Layer & 37 weeks & Drowsiness and respiratory signs \\
\hline P-01 & Pigeon & 6 months & Drowsiness and inappetance \\
\hline
\end{tabular}

Histopathology

Tissue were fixed in 10\% neutral buffered formalin, processed for paraffin embedding, sectioned and stained with haematoxylin and eosin following standard procedure (Luna, 1968).

Virus isolation in embryonated chicken eggs and cell culture

Tissue samples from larynx, trachea and lungs were pooled and homogenized using sterile mortar and pestle to make a $20 \%(\mathrm{w} / \mathrm{v})$ suspension in phosphate-buffered saline (PBS) containing gentamycin $500 \mu \mathrm{g} / \mathrm{mL}$. About $200 \mu \mathrm{L}$ of each sample was 
inoculated into each of three 10-day-old embryonated chicken eggs through allantoic sac route of inoculation (Alexander, 2009). The eggs were incubated at $37^{\circ} \mathrm{C}$ for six days and candled twice daily. Any death during the first 24 hours of incubation was considered non-specific and discarded. All the embryos that died or survived till day 6 post-inoculation were chilled at $4^{\circ} \mathrm{C}$ for one hour. The allantoic fluid was aspirated carefully and stored in sterile screw-capped vials and stored at $-70^{\circ} \mathrm{C}$.

For virus isolation in cell culture, primary chicken embryo fibroblast (CEF) cell culture was prepared from 10-day-old chicken embryos following standard procedure (Freshney, 1983; Schat and Purchase, 1989). Each sample was inoculated into each of two 25 sq. cm. flasks containing fully confluent CEF monolayer @ $200 \mu \mathrm{L}$ per flask. The flasks were incubated at $37^{\circ} \mathrm{C}$ in a humidified incubator and the cells were examined daily under an inverted microscope for the appearance of any cytopathic effects (CPE). Following the development of maximum CPE or at the end of the incubation period (day 6 post-inoculation), the cell culture fluid was harvested after three cycles of freezing and thawing and stored in small aliquots at $-70^{\circ} \mathrm{C}$.

\section{Haemagglutination and haemagglutination-inhibition test}

To detect the presence of NDV, the allantoic fluid was subjected to slide HA test and microtitre plate HA and HI test following the standard procedure (Alexander, 2009). Hyperimmune chicken anti-NDV serum, raised in chickens by repeated inoculation with a NDV vaccine virus (RDV, Department of Livestock Services, Dhaka), was used in HI test.

\section{RT-PCR}

The presence of NDV in the allantoic fluid and tissue culture supernatant was further reconfirmed by RT-PCR. In brief, RNA was extracted from HI positive allantoic fluids and tissue culture fluid using Qiagen RNeasy Extraction Kit (Hilden, Germany) following the protocol provided by the manufacturer. The extracted RNA was subjected to RT-PCR with Qiagen One Step RT-PCR Kit (Hilden, Germany). A primer pair NDV-F2 (5'-TGGAGCCAAACCGCGCACCTGCGG-3') and NDV-R2 (5'GAGGATGTTGGCAGCAT-3') were used to amplify a $766 \mathrm{bp}$ genome fragment containing a part of the matrix $(\mathrm{M})$ protein gene $\left(3^{\prime}\right.$ end) and a part of the fusion $(\mathrm{F})$ protein gene ( $5^{\prime}$ end) (Mase et al., 2009). The following thermal profile was used: reverse transcription at $50^{\circ} \mathrm{C}$ for 30 minute followed by initial denaturation and activation of Taq polymerase at $95^{\circ} \mathrm{C}$ for 15 minute and then 30 cycles of PCR with denaturation at $94^{\circ} \mathrm{C}$ for 30 second, annealing at $55^{\circ} \mathrm{C}$ for 30 second, extension at $72^{\circ} \mathrm{C}$ for one minute, and final extension at $72^{\circ} \mathrm{C}$ for 10 minute. The amplified RT-PCR products were subjected to agarose gel electrophoresis and the resulting cDNA band was visualized in an image documentation system. An NDV vaccine virus (RDV) was used as the positive control. 


\section{Results and Discussion}

At necropsy seven out of 11 cases were tentatively diagnosed as Newcastle disease. The gross pathological changes in these birds included haemorrhage on the tip of the glands of proventriculus, button-like ulcers in the wall of intestine, haemorrhagic caecal tonsils, congested larynx and trachea with excess mucus in the lumen and congestion of lungs. Histopathological examination of the respiratory tissues from ND-suspected chickens showed congestion and haemorrhage in the wall of the bronchus and bronchiole and in the alveoli of lungs. Some birds showed thickened alveolar septa with haemorrhage and congestion. Cellular infiltrations were minimal. Following embryo inoculation, five (C-21, C-50, C-161, C-162 and P-01) out of seven ND suspected samples produced death of all the three inoculated embryos on second passage (Table 2).

Four out of five embryo-lethal samples also produced CPE in primary CEF cell culture in the first passage. The effect of sample C-21 in cell culture could not be interpreted due to bacterial contamination. The other two ND-suspected samples (C56 and C-67) did not cause any embryo mortality, however, C-67 produced CPE in cell culture in the first passage but C-56 appeared to have bacterial contamination. The CPE was initially characterized by increased granularity, rounding and vacuolation of infected cells (Fig. 1). The CPE became more obvious on $2^{\text {nd }}$ and $3^{\text {rd }}$ passage. Formation of syncytia was also found which was most conspicuous with sample C-162 ( $2^{\text {nd }}$ passage) and C-67 ( $3^{\text {rd }}$ passage).
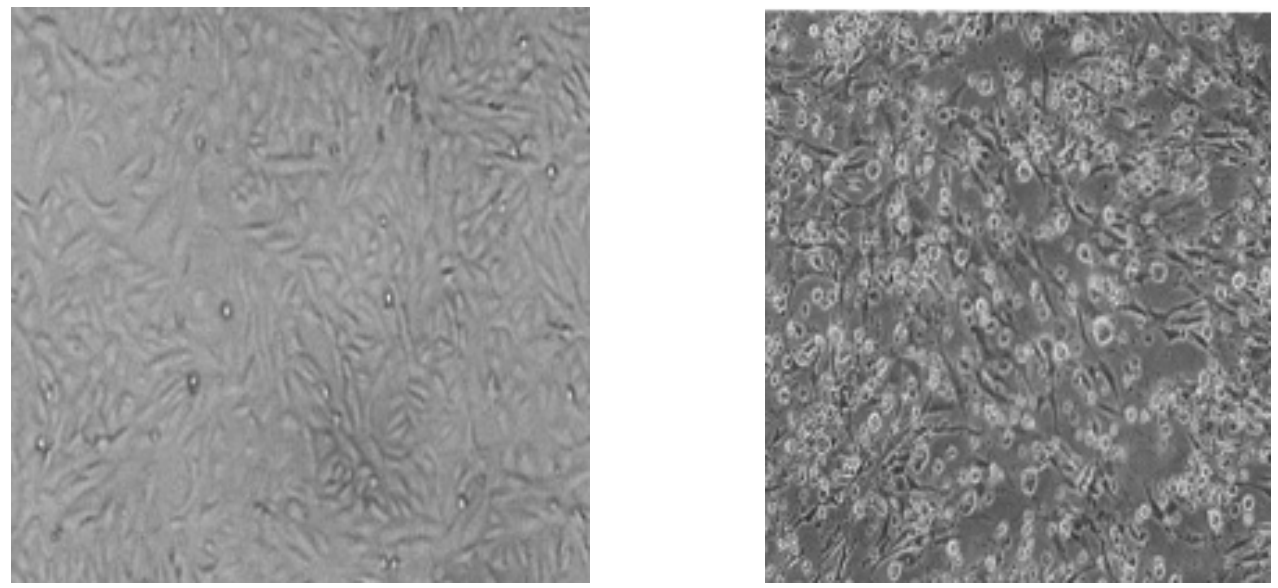

Fig. 1. CPE characterized by rounding of infected cells in CEF cell monolayer following infection with NDV. Left: uninfected control, Right: 72 hours after infection. (10X objective)

Allantoic fluids from embryos inoculated with samples C-21, C-50, C-161, C-162 and P-01 gave positive reaction to slide and microplate haemagglutination test. Supernatant of CEF cell culture inoculated with C-67 sample also gave positive results in haemagglutination test. Haemagglutinating activity of these samples was inhibited by NDV-specific hyperimmune serum in HI test, which is confirmatory for NDV (Alexander, 2009). 
Table 2. Necropsy findings, tentative diagnosis and the results of virus isolation in chicken embryos and CEF cell culture and virus identification by HA and $\mathrm{HI}$ test

\begin{tabular}{|c|c|c|c|c|c|c|}
\hline $\begin{array}{l}\text { Sample } \\
\text { No. }\end{array}$ & Major necropsy findings & $\begin{array}{c}\text { Tentative } \\
\text { diagnosis at } \\
\text { necropsy }\end{array}$ & $\begin{array}{c}\text { Embryo } \\
\text { mortality (on } \\
2^{\text {nd }} \text { passage) }\end{array}$ & $\begin{array}{l}\text { CPE in } \\
\text { cell } \\
\text { culture }\end{array}$ & HA & $\begin{array}{l}\text { HI with } \\
\text { anti-NDV } \\
\text { serum }\end{array}$ \\
\hline C-21 & $\begin{array}{l}\text { Haemorrhage in } \\
\text { proventriculus, congested } \\
\text { larynx, trachea and lung }\end{array}$ & $\begin{array}{l}\text { Newcastle } \\
\text { disease }\end{array}$ & $3 / 3^{*}$ & $?$ & + & + \\
\hline C-39 & $\begin{array}{l}\text { Excess mucus in trachea } \\
\text { and congested lung }\end{array}$ & Colibacillosis & $1 / 3$ & - & - & - \\
\hline$C-40$ & $\begin{array}{l}\text { Excess mucus in trachea } \\
\text { and congested lung }\end{array}$ & Colibacillosis & $0 / 3$ & - & - & - \\
\hline$C-50$ & $\begin{array}{l}\text { Haemorrhage in } \\
\text { proventriculus, button like } \\
\text { ulcer on intestinal mucosa, } \\
\text { congested larynx, trachea } \\
\text { and lung, }\end{array}$ & $\begin{array}{l}\text { Newcastle } \\
\text { disease }\end{array}$ & $3 / 3$ & + & + & + \\
\hline$C-56$ & $\begin{array}{l}\text { Haemorrhage in } \\
\text { proventriculus, button like } \\
\text { ulcer on intestinal mucosa, } \\
\text { congested larynx, trachea } \\
\text { and lung, }\end{array}$ & $\begin{array}{l}\text { Newcastle } \\
\text { disease }\end{array}$ & $0 / 3$ & $?$ & - & - \\
\hline C-67 & $\begin{array}{l}\text { Haemorrhage in } \\
\text { proventriculus, congested } \\
\text { larynx, trachea and lung }\end{array}$ & $\begin{array}{l}\text { Newcastle } \\
\text { disease }\end{array}$ & $0 / 3$ & + & + & + \\
\hline C-139 & $\begin{array}{l}\text { Congested trachea and } \\
\text { lungs }\end{array}$ & $\begin{array}{l}\text { Non-specific } \\
\text { respiratory } \\
\text { infection } \\
\end{array}$ & $0 / 3$ & - & - & - \\
\hline C-161 & $\begin{array}{l}\text { Haemorrhage in } \\
\text { proventriculus, button like } \\
\text { ulcer on intestinal mucosa, } \\
\text { congested larynx, trachea } \\
\text { and lung, }\end{array}$ & $\begin{array}{l}\text { Newcastle } \\
\text { disease }\end{array}$ & $3 / 3$ & + & + & + \\
\hline C-162 & $\begin{array}{l}\text { Haemorrhage in } \\
\text { proventriculus, button like } \\
\text { ulcer on intestinal mucosa, } \\
\text { congested larynx, trachea } \\
\text { and lung, }\end{array}$ & $\begin{array}{l}\text { Newcastle } \\
\text { disease }\end{array}$ & $3 / 3$ & + & + & + \\
\hline C-308 & $\begin{array}{l}\text { Congested lung, } \\
\text { haemorrhage on heart }\end{array}$ & $\begin{array}{l}\text { Non-specific } \\
\text { septicaemic } \\
\text { disease }\end{array}$ & $0 / 3$ & - & - & - \\
\hline P-01 & $\begin{array}{l}\text { Haemorrhage in } \\
\text { proventriculus }\end{array}$ & $\begin{array}{l}\text { Newcastle } \\
\text { disease }\end{array}$ & $3 / 3$ & + & + & + \\
\hline
\end{tabular}

* Number of embryos died/number inoculated, ' - ' indicates negative result and ' + ' indicates positive results. '?' indicates that results could not be interpreted due to bacterial contamination. 
All the five HA- and HI-positive allantoic fluids also gave positive reaction in RT-PCR for NDV. A $766 \mathrm{bp}$ fragment covering a part of matrix protein and fusion protein genes was successfully amplified (Fig. 2).

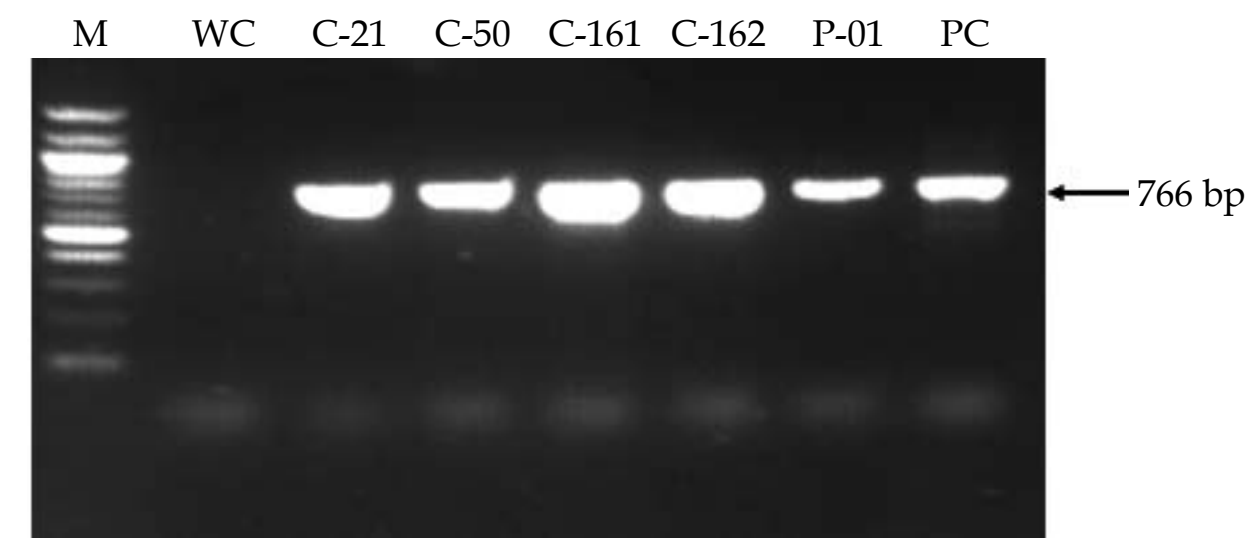

Fig. 2. Amplification of NDV genome fragment (766 bp) by RT-PCR. M = Marker (100bp), WC = Water Control, PC = Positive Control (RDV), C-21, C-50, C-161, C-162, P-01 are NDV isolates

Although seven cases were diagnosed as ND based on necropsy findings, NDV could be successfully isolated by embryo inoculation from five samples. Four out of these five samples could also be grown in cell culture and one sample appeared to have bacterial contamination. Among the two remaining samples one did not cause embryo mortality but yielded virus in cell culture; the other was negative on embryo inoculation and unsuitable for virus isolation in cell culture due to bacterial contamination. Treatment with gentamycin $(500 \mu \mathrm{g} / \mathrm{mL})$ did not remove the bacterial contamination completely; efficacy of other antibiotic treatment was not tested. So for successful isolation of NDV, it is necessary to avoid excessive bacterial contamination. The CPE characterized by increased granularity, rounding and vacuolation of infected cells followed by the formation of syncytia were typical of NDV (Ravindra et al., 2009; Mehrabanpour et al., 2010). A relatively large number of syncytia was found with sample C-67 and C-162. This may be related to virulence of the virus (Reeve and Poste, 1971). However, further pathogenicity studies will be needed to measure the virulence.

Although virus isolation and serological identification followed by in vivo pathogenicity testing still remains as the gold standard, RT-PCR offers a reliable tool for quick detection of NDV. Moreover, RT-PCR products can be used for downstream pathotypic and genetic analysis (Toyoda et al., 1989; Collins et al., 1993; Seal et al., 1995).

In conclusion, six isolates of NDV, five from chickens and one from a pigeon, were successfully isolated and identified from field outbreaks. RT-PCR could be a rapid and sensitive tool for the detection of NDV. Pathotypic and genotypic characterization of the virus isolates are now in progress. 


\section{References}

Alexander DJ 1997: Newcastle disease and Avian paramyxovirus infections. In: Calnek BW, Bernes HJ, Beard CW, McDougald LR, Saif YM (editors), Disease of Poultry, $10^{\text {th }}$ edn. Iowa State University Press, Ames, USA, pp. 541-569.

Alexander DJ 2009: Newcastle disease, In: OIE Manual of Diagnostic Tests and Vaccines for Terrestrial Animals (Paris). http://www.oie.int/fileadmin/Home/eng/Health_ standards/tahm/2.03.14_NEWCASTLE_DIS.pdf (Accessed on 1 July 2012)

Barman LR, Islam MN, Flensburg MF, Permin A, Petersen SL, Islam MR 2010: Newcastle disease vaccination regimen comprising both lentogenic and mesogenic strains is more effective than lentogenic strain only. Bangladesh Veterinarian 27 1-7.

Chowdhury TIMFR, Sarker AJ, Amin MM, Hossain WIMA 1981: Studies of Newcastle disease in Bangladesh. Bangladesh Veterinary Journal 15: 1-9.

Collins MS, Bashiruddin JB and Alexander DJ 1993: Deduced amino acid sequences at the fusion protein cleavage site of Newcastle disease virus showing variation in antigenicity and pathogenicity. Archives of Virology 128 363-370.

Freshney RI 1983: Culture of Animal Cell. A. Manual of Basic Technique. Alan R. Liss, Inc., New York, USA.

Gohm DS, Barbara T, Hofmann MA 2000: Detection of Newcastle disease virus in organs and feces of experimentally infected chickens using RT-PCR. Avian Pathology 29 143-152.

Jestin V, Jestin A 1991: Detection of Newcastle disease virus RNA in infected allantoic fluids by in vitro enzymatic amplification (PCR). Archives of Virology 118 151-161.

Kaleta EF, Baldauf C 1988: Newcastle disease in free-living and pet birds. In: Alexander DJ (edn) Newcastle Disease, Kluwer Academic Publishers, Boston. pp. 197-246.

Kant A, Koch G, Van Riizelaar DJ, Balk F, Ter Huurne A 1997: Differentiation of virulent and non-virulent strains of Newcastle disease virus within 24 hours by polymerase chain reaction. Avian Pathology 26 837-849.

Lamb RA, Kolakofsky D 2001: Paramyxoviridae: the viruses and their replication. In: Knipe DM and Howley PM (editors) Field's Virology, $4^{\text {th }}$ edn. Lippincott \& Wilkins, Philadelphia, USA, pp. 1305-1340.

Luna LG 1968: Manual of Histopathologic Staining Methods of the Armed Forces Institute of Pathology, 3rd edition. McGrow Hill Book Company, London.

Mase M, Inoue T, Imada T 2009: Genotyping of Newcastle Disease Viruses Isolated from 2001 to 2007 in Japan. Journal of Veterinary Medical Science 71 1101-104.

Mehrabanpour MJ, Dardas H, Pourbakhsh SA, Hoseini SMH, Motamedifar M, Mohammadi A 2010: Plaque formation of LaSota pathogenic strain of Newcastle disease virus adapted in chick embryo fibroblast cells. Archives of Razi Institute 62 7-13. 
Noor M, Rajib DMM, Chowdhury EH, Islam MR, Das PM 2005: Pathogenic characterization of Newcastle disease virus field isolates. Progressive Agriculture 16 91-98.

Ravindra PV, Tieari AK, Ratta B, Chaturvedi U, Sudesh KP, Chauhan RS 2009: Newcastle disease virus-induced cytopathic effect in infected cells is caused by apoptosis. Virus Research 141 13-20.

Reeve P, Poste G 1971: Studies on the cytopathogenicity of Newcastle disease virus. Relation between virulence, polykaryocytosis and plaque size. Journal of General Virology 11 17-24.

Saha S, Islam MA, Rahman MM, Alam KHT 1998: Efficacy of an inactivated Newcastle disease virus vaccine prepared from a local isolate. Bangladesh Veterinary Journal 32 57-62.

Schat KA, Purchase HG 1989: Cell culture methods, In: A Laboratory Manual for the Isolation and Identification of Avian Pathogens, 3rd edn., edited by American Association of Avian Pathologists, USA, pp. 167-175.

Seal BS, King DJ, Bennett JB 1995: Characterization of Newcastle disease virus isolates by RT-PCR coupled to direct nucleotide sequencing and development of sequence database for pathotype prediction and molecular epidemiologic analysis. Journal of Clinical Microbiology 33 2624-2630.

Talha AFSM, Hossain MM, Chowdhury EH, Bari ASM, Islam MR, Das PM 2001: Poultry diseases occurring in Mymensingh district of Bangladesh. Bangladesh Veterinarian 18 20-23.

Toyoda T, Sakaguchi T, Hirota H, Gotoh B, Kuma K, Miyata T, Nagai Y 1989: Newcastle disease virus evolution. II. Lack of gene recombination in generating virulent and avirulent strains. Virology 169 273-282.

Zhang L, Pan Z, Geng S, Chen X, Hu S, Liu H, Wu Y, Jiao X, Liu X 2010: Sensitive, seminested RT-PCR amplification of fusion gene sequences for the rapid detection and differentiation of Newcastle disease virus. Research in Veterinary Science 89 282-289. 